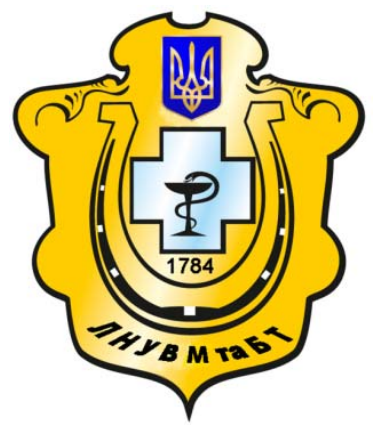

Науковий вісник Львівського національного університету ветеринарної медицини та біотехнологій імені С.З. Гжицького

Scientific Messenger of Lviv National University of Veterinary Medicine and Biotechnologies named after S.Z. Gzhytskyj

doi:10.15421/nvlvet7202

ISSN 2413-5550 print

ISSN 2518-1327 online

$\underline{\text { http://nvlvet.com.ua/ }}$

\title{
The Effects of Stress on Acute Phase Proteins of Cattle
}

\author{
Necmettin Sarp SEVGISUNAR, Şima ŞAHINDURAN \\ sahinduran@mehmetakif.edu.tr \\ Department of Internal Medicine, Faculty of Veterinary Medicine, \\ Mehmet Akif Ersoy University, Burdur, Turkey
}

Stress occurs with the pressure of external and internal (infectious or non-infectious) causes which forces change in animals. This stress not only emerge with behavioral or clinical signs, but also will result with immune response formed by body. Understanding and evaluating this subclinic response is also possible with the help of Acute Phase Proteins (APP-AFP) which are released by tissues and organs when exposed to external and internal changes as well as known hormonal changes.

Cattle are fed because of their economical importance and the inflammatory processes have influence on their yield levels. Because the stress is laying under all these health problems, also it is getting attention how stress effect the animals.

Stress can be divided into main four groups: physical (mechanical), inflammatory (infectious), behavioral and other stress factors. The main APPs which all groups mostly using in their studies are serum amyloid A (SAA) haptoglobin (Hp), ceruloplasmin (CP), fibrinogen (Fb), lipopolisakkarit binding protein (LBP) ve $\alpha_{1}$-Acid Glycoprotein (AGP).

Key words: Acute phase protein, cattle, stress

\section{Citation:}

Necmettin Sarp Sevgisunar, Şima Şahinduran (2016). The Effects of Stress on Acute Phase Proteins of Cattle. Scientific Messenger LNUVMBT named after S.Z. Gzhytskyj, 18, 4(72), 107-113.

\section{Özet}

Hayvanlarda değişen diş ve iç (enfeksiyöz veya non-enfeksiyöz) şartların baskısı sonucunda stres oluşur. Oluşan stres sadece davranışsal veya klinik olarak değil, vucüt tarafından oluşan verilen immun yanıt olarak da karşımıza çıkmaktadır. Bu sub-klinik yanıtın anlaşılabilmesi ve yorumlanabilmesi ise bilinen hormon değişimleri dişında iç ve dış değişimlere maruz kalan doku ve organlar tarafindan salınan Akut Faz Proteinleri (AFP) yardımıyla da olabilmektedir.

Sığırlar ekonomik değeri olan hayvanlardır ve yaşadıkları yangısal süreçler verim düzeylerini çeşitli şekillerde etkilemektedir. Sağlık sorunlarının temelinde stres faktörü yatmakta olduğu için stresin hayvanları nasıl etkilediği de önem kazanmaktadır.

Stres fiziksel (mekanik), yangısal (enfeksiyöz), davranışsal stres ve diğer stres faktörleri olmak üzere dörde ayrılır. $\mathrm{Bu}$ dört temel grubun da en sık çalıştığı AFP'leri serum amiloid A (SAA), haptoglobin (Hp), seruloplazmin (Cp), fibrinojen (Fb), lipopolisakkarit bağlayıcı protein (LBP) ve $\alpha 1-$ Asit Glikoprotein (AGP)'dir.

Anahtar sözcükler: Akut faz protein, sığır, stres

\section{GíRIŞ}

Stres tanım olarak canlının dış ve iç değişimlere karşı verdiği tepkidir $(3,26)$. Yani hayvanın bir dış etkene karşı uyum gösteremeyip başa çıkamaması ve genetik potansiyelini gösterme şansını bulamaması demektir (15). Homeostazisi bozan bu değişimler birkaç temel noktada birbirinden ayrilmakla beraber sonuçta vücutta yangısal reaksiyonlar oluşturur (24).

Yangisal reaksiyonlar hayvanda subklinik ve klinik belirtilere yol açar. Klinik anlamda depresyon ya da depresif hal dediğimiz hal içerisine giren hayvanın önce iştahı kesilir, sonra hareketliliği azalır, dolaşımı yavaşlar. Subklinik anlamda ise metabolik değişimler başlatır (26). Bu metabolik değişimler kısaca lenfositler ve makrofajlardan önce sitokinlerin salınımıyla akut faz reaksiyonlarını başlatır (AFR), devamında ise karaciğerden akut faz proteinlerinin (AFP) salınımına neden olur.

Sığırlar üzerinde yapılan bazı çalışmalar hem hayvan refahının, hem de sürü sağlığının sağlanmasında önemli roller üstlenmiştir (28). Genetik seçilim ve çevresel baskı çiftlik hayvanlarında konfor eksikliğinden ölüme varabilen istenmeyen sonuçlara predispoze kılmaktadır. Hayvanlara daha iyi refah uygulamaları sunabilmek ve stres sebebi olan çevresel ve/veya yönetimi izlemek için potansiyel rol AFP'leri tarafindan oynanmaktadır (33). 


\section{STRESIN MEKANIZMASI}

Stres, aslında bir sebepten çok sonuçtur. Yani vücudun karşı karşıya kalmış olduğu durumdan çıkabilmesinin tek yolu stres oluşturmaktır. Stresin belli miktarının insanlarda bilinç ve algı düzeylerini yükselttiği bildirilmiştir (26). Bununla birlikte, hayvanlarda yapılmış çalışmalar olayın insana göre daha farklı işlediğini göstermektedir.

Strese bağlı olarak hayvanda oluşan sub-klinik belirtiler plazma kortizon, norepinefrin, vazopressin ve aldosteron miktarlarında artış görülmesidir. Devamında ya da direk olarak beslenme bozuklukları oluşur, bu da plazma insülin, leptin gibi enzimlerin miktarlarında artışa; insülin benzeri büyüme faktörü (IGF), tiroit stimule eden hormon (TSH) gibi metabolitlerin de azalmasına neden olur. Bunun yanında plazmadaki kortizon aynı zamanda lökositleri ve karaciğeri de uyararak yangısal sitokinlerin (IL-1, IL-6, IL-12, TNF- $\alpha$ ) salınımina neden olur. Yangısal sitokinlerin salınımı sonucunda AFP'leri devreye girer (26).

Vücutta oluşan bu değişimler hiperaljezi, letarji, durgunluk veya uykulu olma hali, lokomotor hareketlerde azalma, çevreye ilginin kaybolması, anoreksi ve kilo kaybı gibi hastalık tablosuyla benzer klinik bulgularla kendini belli eder (26).

Ayrıca, gün boyu alınan ışık miktarının da insanlarda depresyon oluşturduğu bildirilmektedir (26). Buna benzer yapılan çalışmalarda ruminantlardaki melatonin seviyesinin üreme fonksiyonları üzerine direk etkisinin varlığı belirtilmiştir (15).

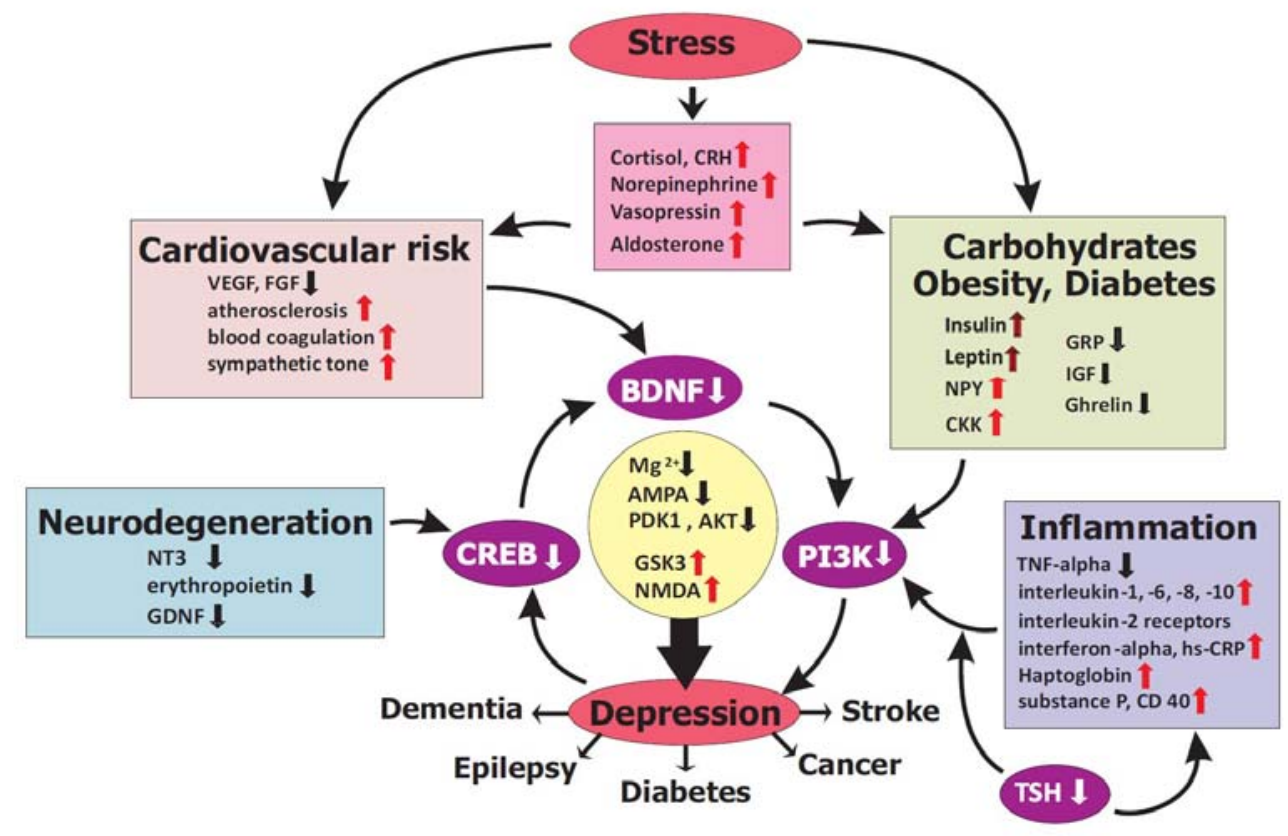

Şekil 2.1. Stresin Reaktif Mekanizması (26)

\section{STRES FAKTÖRLERI}

Stresin bilimsel yanı karmaşık bir başlıktır. Aslında farklı kişiler, birbirinden farklı stres tanımlaması, adlandırması ve bakış açısı kullanmaktadır. Her şeye rağmen, kolektif olarak stresin organizmada homeostazisi bozan iç ve dış baskılar sonucunda ortaya çıktığı kabul edilmektedir (3). Siğırlarda stres faktörü olarak belirlenebilecek birçok konu vardır. Ancak bunların belli başlı alt başlıklara ayrılmasında fayda vardır. Bu ayrımın yapılmasının en önemli sebebi benzer çalışmaların ufak nüanslarla gerçekleştirilmiş olmasından kaynaklı her çalışmanın aslında birbirinden bağımsız verileri ve sonuçları varmış gibi gözükmesidir.

Sığırlarda görülen stres faktörlerini belli başlı dört ana gruba ayırmak mümkündür. Bunlar,

1. Fiziksel (Mekanik) Stres

2. Yangisal (Enfeksiyöz) Stres

3. Davranışsal Stres

4. Diğer Stres Faktörleri

\section{1. Ölçümü Yapılan Akut Faz Proteinleri}

Sığırlar diğer hayvanlardan farklı immun yanıtlara sahip olduğu için doğal olarak AFP'leri de farklılık göstermektedir. Bu bağlamda çalışmalarda en sık Serum Amyloid A (SAA) ve Haptoglobin'in (Hp) kullanıldı̆̆ı, devamında daha nadir olarak Seruloplazmin (Cp) ve Fibrinojen'in $(\mathrm{Fb})$, çok az sayıda yapılan çalışmada ise Lipopolisakkarit Bağlayıcı Protein'in (LBP) ve $\alpha_{1}-$ Asit Glikoprotein' in (AGP) kullanıldığı bildirilmiştir.

Serum Amyloid A sığırlarda sık kullanılan AFP'lerinden biridir ve sağlıklı sığırların kanında oldukça düşük miktarda bulunmaktadır. Vücutta yüksek yoğunluklu lipoprotein ve kolesterolün taşınmasında yardımcidır (33).

Haptoglobin'in vücuttaki tam fonksiyonel rolü hala tam olarak anlaşılamamıştır, ancak akut faz proteini olarak haptoglobini kandaki serbest hemoglobinle kompleksler oluşturarak demirin kullanımını sınırladığı şeklinde düşünülebilir (5). $\mathrm{Bu}$ anlamda haptoglobin serbest demirin bakteriler tarafindan kullanılmasını 
engeller ve böylece bakteriyel büyümeyi engeller (17). Haptoglobin stres altında olmayan sığırların kanında ölçülemez. Yangısal stres durumlarında Hp konsantrasyonunun hızla artması sığırlarda en çok değerlendirilen akut faz proteini haline getirmiştir (9). Haptoglobini ölçmenin avantajları hayvanları karşılaştırırken kalitatif ve kantitatif yaklaşımların kullanılabilmesi ve uyarım sonrası çok hızlı bir yükselme göstermesidir. Kısıtlı bir dezavantajı da çeşitli derecede hemolize uğramış kan örnekleri serbest demire bağlanmadan kaynaklı ölçüm farklılıklarına neden olabilmektedir.

Seruloplazmin (Cp) memelilerde primer bakır taşıyıcı proteindir. Birincil görevi yangısal durumlarda bakırın tüm vücuda taşınmasıdır, böylece bakır/çinko süperoksit dismutaz enzimi gibi güçlü enzim sistemlerini destekler (32). Kanda bulunan bakırın yaklaşık \%95'inin seruloplazmin ile bağlantılı olduğu bildirilmiştir (12). Hp'den farklı olarak Cp hem stres altında, hem de stres altında olmayan sığırlarda bulunmaktadır ve yangısal bir uyarı sonrası normal seviyesinin 2-5 katı artabilmektedir. Seruloplazmin serum ve plazma örnekleri saklanırken yüksek derecede stabildir. Ancak besinsel bakır durumuna yanıtı, göz önünde bulundurulması gereken dezavantajdır. Cp'in düşük veya yüksek dozları bazen bakır alımına bağlıdır ve bir akut faz proteini olarak reaktifliği besinsel bakır durumuyla ilişkilidir $(4,5)$.

Fibrinojen kanın pıhtılaşması ve doku onarımı için önemli bir proteindir. Stres altında olan veya olmayan sığırlarda seruloplazmine benzer olarak, fibrinojen de ölçülebilmektedir ve sığırlarda yangısal durumlarda kullanılmaktadır. Yangısal reaksiyon sırasında fibrinojen 5-10 kat arası artış gösterir. Fibrinojen tam olarak açıklanamamakla beraber seruloplazmin ile bağlantı içindedir ve besinsel kaynaklı olabilir. Stres altındaki sığırlarda $\mathrm{Fb}$ konsantrasyonları oldukça yüksek ve $\mathrm{Cp}$ konsantrasyonu oldukça düşük çıkmıştır $(3,4)$.

Lipopolisakkarit Bağlayıcı Protein (LBP) bakteriye karşı verilen doğal immun yanıtın anahtar elemanlarından biridir. LBP kandaki yoğunluğuna göre proenflamatuar veya antienflamatuar görev alır.

$\alpha_{1}$-Asit Glikoprotein (AGP) edinsel bağışıklığ düzenleyen ve enfeksiyon ya da yaralanma durumlarında artış gösteren bir AFP'dir (27). Lenfosit transformasyonu ve immun sistem ile ilişkili olduğu bilinmektedir.

\subsection{Fiziksel (Mekanik) Stres}

Sığırlarda fiziksel stresten bahsedildiğinde bunun içerisine özellikle transport, barındırma koşulları, altlık materyali, kastrasyon gibi maddeler dahil olmaktadır.

Transport ile ilgili koyunlarda yapılmış bir çalışmada, transport öncesi ve sonrası iki gruba ayrılan hayvanlardan kan örnekleri toplanarak serum SAA, Hp ve $\mathrm{Fb}$ ölçümleri yapılmıştır. Yapılmış olan ölçümlerde 6 saatte ortalama $80 \mathrm{~km} / \mathrm{sa}$ hıda

$490 \mathrm{~km}$ taşınan koyunlarda kontrol grubuna (transport yapılmamış) göre $\mathrm{Hp}$ ve SAA değerlerinde belirgin yükselme görülmüş, ancak $\mathrm{Fb}$ düzeyinde bu yükseliş saptanmamıştır (40).

İrlanda'da bir çiftlikten İspanya'ya hem deniz, hem de karayoluyla uzun süren bir transport süreci sırası ve sonrasında yapılan haptoglobin ve fibrinojen ölçümlerinde her iki AFP'ne de yanıt alındığı, ancak serum $\mathrm{Hp}$ konsantrasyonundaki yükselişin serum $\mathrm{Fb}$ konsantrasyonuna göre daha yüksek olduğu belirtilmiştir (16).

24 saat taşınma (TRANS), 24 saat yem ve su kısıtlaması (REST) ve kontrol gruplarıyla yapılan bir çalışmada Seruloplazmin ve Haptoglobulin stres indikatörü olarak kullanılmış ve TRANS ve REST gruplarının her ikisinde de plazma kortizol miktarıyla beraber $\mathrm{Hp}$ ve $\mathrm{Cp}$ miktarlarında önemli bir değişim olduğu ortaya konmuştur. Ayrıca su ve yem kısıtlamasına gidilen besiye alınmış sığırlarda $\mathrm{Hp}$ ve $\mathrm{Cp}$ değerlerinin daha geç normal sınırlara döndüğü belirlenmiştir. Sonuç olarak 24 saat yolda taşıma ve 24 saat yem ve su kısitlaması yağ rezervlerinin mobilize olmasına neden olmuş, nöroendokrin ve AFR'nu tetiklemiş ve etçi sığırların performanslarını düşürmüştür. Ancak, AFR'nu ilk olarak yiyecek ve su kisitlaması başlatmış ve uzun mesafelere taşınan besi sığırlarında azalan yemden yararlanma görülmüştür (31).

Buzağılarda fiziksel stresin AFP'leri üzerine etkisini ölçen Alsemgeest ve ark. (1), 15 günlükten itibaren 7 buçuk aylık yaşa kadar plastik altlıklı ve tahta altlıklı kulübelerde barındırdıkları iki grup buzağıda serum SAA, Hp, kortizon ve aldolaz miktarlarını ölçmüşlerdir. Yapılan ölçümler sonucunda sadece SAA miktarında gözle görülür bir değişim olduğunu, serum Hp, kortizon ve aldolaz miktarlarında belirgin bir değişim olmadığını bildirerek buzağılarda fiziksel stresin belirteci olarak SAA'nın kullanılabileceğini bildirmişlerdir.

Uzun süren transport sonrası serum $\mathrm{Hp}$ ve $\mathrm{Fb}$ ölçümleri yapılan bir çalışmada dişilerin erkeklere göre daha yüksek serum AFP'lerine ve daha uzun süren AFP pik düzeylerine sahip olduğu belirlenmiştir (16).

Fiziksel stres içerisinde yer alabilecek bir kavram da organların patolojik olarak yer değiştirmesi olabilir. Bu bağlamda abomasum deplasmanlı ineklerden alınan kan ve peritoneal sıvı örneklerinde $H p$ ve SAA yanı sıra oksidatif stres ve enzim aktiviteleri ölçülmüş, LDA ve RDA olgularının her ikisinde de kan $\mathrm{Hp}$ ve SAA düzeyinin yükseldiği tespit edilmiştir. Bununla beraber peritoneal sıvıdan yapılan ölçümde sadece Hp ölçülmüş ve her iki tarafa deplase olan hayvanlarda bu değer yine yüksek bulunmuştur (30).

\subsection{Yangısal (Enfeksiyöz) Stres}

Yangısal stres özellikle hastalıklar açısından irdelendiğinde çok zengin ve geniş bir konu olmasına rağmen çalışmada sadece stres konusunu içeren literatürlere yer verilmiştir.

Dünyada solunum sistem hastalıkları arasında önemli bir yeri bulunan Mikoplazma enfeksiyonlarının yaygın olduğu bir bölgede yapılmış iki farklı aşılama etkinliğinin ölçümünde de $\operatorname{IgM}$, IgA, IgG1, IgG2 ve sitokinlerin (IL-1 $\beta$, IL-2, IL4, IL-6, IFN- $\gamma$, and TNF- $\alpha$ ) ölçümleri yapılarak bulunan sonuçlar değerlendirilmiştir.

(43)

Finlandiya'da 13 işletmede yapılmış bir solunum sistem bakteriyel ve viral hastalık taramasında buzağılarda M. dispar, diğer mikoplazmalar, $\mathrm{P}$. 
multocida, Pasteurella sp., F. necrophorum ve A. pyogenes sirasiyla $90.5 \%, 60.7 \%, 14.3 \%$,

$1.2 \%, 6.0 \%$ ve $2.4 \%$ oranında izole edilmiştir ancak M. bovis'e rastlanmamıştır. En yaygın $\mathrm{Fb}, \mathrm{Hp}$, SAA, AGP, LBP ölçümleri yapılmış, AGP değerlerinin SAA ve Hp'den daha uzun süre dolaşımda kaldığı bildirilmiştir (35).

LBP ile ilgili yapılmış bir çalışmada M. haemolytica ile enfekte edilmiş buzağılardan elde edilen kan örnekleri $\mathrm{Hp}$, SAA ve LBP yönünden incelenerek LBP'nin serum düzeyinin diğer iki AFP'den daha kısa sürede (6 saat) yükseldiğini ve daha uzun süre seyrettiğini bildirmişlerdir (42).

Yardımcı testler, metabolik profil ve ileri saha teknikleri de sığır solunum hastalıklarının (SSH) teşhis metotları olarak aktif biçimde araştırılmaktadır. Hastalığa dair tek bir belirli tanımlayıcı girişimleri sonuçsuz kalmıştır. SSH çalışmalarında serum kortizon konsantrasyonları ölçülmüş, ancak kortizon konsantrasyonları hem hastalık hem de stres durumlarında yükselmiştir. Ayrıca gece-gündüz düzey farklılığı ve dolaşımdaki konsantrasyonunun çabuk değişmesi değerlendirmeyi zorlaştırmaktadır.

Bakteriyel endotoksin varlığı ile tetiklenen AFR ve AFP ile ilgili yapılan bir çalışmada SAA, AGP, sitokinler ve klinik bulgular çalışmanın 2 saat öncesi ve 8 saat sonrası ölçülmüş, AFP olarak sadece SAA'nın varlığında bir değişim olduğu bildirilmiştir (8).

E.coli ve rumen asidozu arasındaki ilişkiyi göstermek için yapılmış bir çalışmada hayvanlara E.coli benzeri reaksiyon gösterecek LPS enjekte edilerek AFR incelenmiştir. Çalışmanın sonucunda düşük rumen pH'1 ve rumende yüksek düzeyde bulunan serbest LPS'nin dışındaki faktörlerin tane yemin tetiklediği SARA sırasındaki yangıdan sorumlu olabileceğini düşündürmektedir (41).

Doğal (fosforillenmiş) ve kısmen fosforillenmemiş AGP'nin sığır polimorfnükleer lökositleri (PMN) ve monositleri üzerindeki antimikrobiyel etkileri değerlendirilen bir çalışmada doğal AGP E.coli'nin PMN ve monositler tarafindan fagosite edilmesini ve öldürülmesini baskılamıştır. E.coli'nin fagositoz ve öldürülmesi AGP'nin (0.9 mg/mL) düzeyinde normal fizyolojik düzeyiyle $(0.3 \mathrm{mg} / \mathrm{mL})$ karşılaştırıldığında daha düşük seviyede gerçekleşmiştir. Defosforilasyonu takiben AGP'nin monositlerdeki fagositozu baskılama ve PMN'lerin E.coli'yi öldürme yeteneği azalmıştır. PMN'lerin ve monositlerin görevleri AGP'nin değişen konsantrasyonları ve fosforilasyon durumlarına göre değişkenlik göstermekte, düşük dozlarda fagositozu aktive ederken yüksek dozlarda fagositozu baskilamaktadır (27).

Domuzlarda yapılmış bir çalışmada 6 farklı gruba doğum sonrası 3 farklı protein düzeyine sahip rasyon uygulanmış ve bu diyete E.coli enfeksiyonu eklenerek doğum sonrası subklinik hastalık tablosu incelenmiştir. Rasyon protein oranı ve Hp, CRP ölçülerek hayvanların klinik tabloları incelenmiştir. Sonuçlara göre hastalık tablosunu açıklamada $\mathrm{Hp}$ değerlerinin tek başına yeterli olmadığı, hayvanların aldıkları rasyondaki protein düzeyine göre de cevabın şekillendiği belirtilmiştir (23).
Akut ruminal asidozun incelendiği bir çalışmada da SAA ve Hp değerleri ölçülerek farklı rasyonlarla beslenen hayvanlarda farklı AFP motifleri belirlendiği bildirilmiştir (13).

Besi için kastre edilmiş sığırlarda yapılan bir çalışmada iki gruba ayrılıp bir gruba önce testosteron enjekte edilmiştir. Daha sonra oluşturulmuş her iki gruba da 5

gün arayla 2 defa LPS uygulanmış, çalışma öncesinde ve sonrasinda serum TNF- $\alpha$, SAA ve Hp miktarları ölçülmüştür. İlk LPS uygulaması sonrası testosteron uygulanan grupta Hp miktarı ikinci LPS uygulamasına kadar yüksek seyretmiştir. İkinci LPS uygulaması sonrası yine testosteron uygulanan grupta Hp miktarı daha yüksek çıkmıştır. Bununla birlikte her iki grupta da SAA miktarı (zaman X konsantrasyon) bazında artış göstermiş, ancak testosteron uygulanan grubun verdiği yanıt kontrol grubuna göre daha şiddetli olmuştur (25).

\subsection{Davranışsal Stres}

Yapılmış birçok çalışma aslında hayvanlardaki davranışsal stresi de ölçmüştür. Bunlara örnek olarak LPS uygulamaları sirasinda hayvanların terleme oranları, ayakta durma süreleri, depresyon veya hiperaktivite takipleri yapılmıştır. Ayrıca buzağılarda yapılan çalışmalarda buzağılar video kamera ile takip edilmiş ve yatma/ayakta durma süreleri incelenmiştir.

Farklı altlıklarda barındırılan sütten kesilmiş buzağıların altlık ve barındırma durumlarına göre yatma ve geviş getirme davranışlarında ciddi azalma görüldüğü ve bu durumun serum Hp ve SAA'ya yansıdığı bildirilmiştir (1).

Transport sonrası bireysel barındırmaya alınarak kompleks stres oluşturulmuş sığırlarda da sosyal izolasyona bağlı diğer hayvanlara seslenme davranışında artış ve serum SAA ve Hp düzeyleri ölçülerek kontrol grubuyla aralarında anlamlı bir fark oluştuğu, bundan dolayı sığırlarda kompleks stres olgularında SAA ve Hp'in belirteç olarak kullanılabileceği bildirilmiştir (29).

Siçanlarda karaciğer enzim aktivitesi (ALT, AST) yanısıra yangısal sitokinler olarak IL-1 $\beta$, IL-6 ve IL12'nin ölçüldüğü uykusuzluk üzerine yapılmış bir çalışmada REM (Rapid Eye Movement) uykusunun önlendiği sıçanlarda yangısal sitokinlerin varlığının belirgin şekilde arttı̆̆ tespit edilmiştir (39). Böylece uykusuzluğun da hayvanlardaki stres faktörlerinden biri olabildiği görülmüştür.

\subsection{Diğer Stres Faktörleri}

Profesyonel işletmelerde yetişkin sığırlar kadar buzağ sağlığı ve yönetimi de önemli bir konudur. Bu bağlamda yapılmış bir çalışmada bir sürüdeki buzağıların subklinik hastalık tablolarını araştırmak amacıyla $\mathrm{Hp}$, SAA ve $\mathrm{Fb}$ ölçümleri lökosit sayımlarıyla birlikte yapılarak buzağ sürü sağlığı kontrol edilmiştir (19).

Kuzularda kolostrumun pasif immunite üzerine pozitif etkileri olduğunun bildirildiği bir çalışmada kolostrum ve kuzu kan örneklerinde $\operatorname{IgG}$ ve Laktoferrin düzeyleri ölçülmüştür (21).

Sindirim sistemi ile ilgili yapılan bir çalışmada sığırların ön mideleri ve abomazumundan sentezlenen AFP'leri ve Western Blot analizleri ortaya konduğunda 
çıkan sonuç sanılanın aksine karaciğer dışındaki diğer dokularda da AFP sentezlendiğini, ancak bunların karaciğerde sentezlenen AFP'ler (özellikle SAA) ile izoform olduğu bildirilmiştir (14).

Yenidoğan buzağılarda yapılmış bir çalışmada ilk 3 hafta ve 2 ay şeklinde oluşturulan 2 grup buzağıda dört sığır AFP'nin (SAA, LBP, Hp and AGP) serum konsantrasyonlarında oluşan yaşa bağlı değişimlerin izlenmiştir. Kolostral SAA'nın pasif transferini ve buzağılardaki SAA izoformlarını gözlemlemek için buzağılardan kan örneği, annelerinden ise kolostrum örnekleri toplanmıştır. AFP'lerinde temporal değişimler hastalık süreçlerinden daha çok, doğum süreci ve/veya kolostrumdaki indükleyici faktörlerle ilişkilendirilmiştir. Görece yüksek SAA ve AGP değerleri hastalık belirteci olarak kullanılan bu değerlerin doğum stresinden kaç gün sonra ölçüldüğünün önemini belirtmektedir. Çünkü yenidoğan buzağıda doğumdan sonra koruma mekanizmalarında kilit rol oynayan AFP'lerde dalgalanma olduğu cazip bir fikir olsa da AFP'ler ve kısmen SAA hayvanın immun yanıtında önemli bir rol oynar (37).

Değişen dozlarda C.psittaci ile enfekte edilen sığırlarda LBP ve solunum stresi ölçülmüş, doz arttıkça hayvanlarda klinik solunum stresi şiddetinin de arttığ görülmüştür. Devamında hayvanlar patofizyolojik olarak incelenmiş ve uygulanan dozun arttırıldığı hayvanlarda daha şiddetli patolojik lezyonlar gördüklerini bildirmişlerdir (38).

Yapılan bir çalışmada, LPS uygulamasını takiben serum $\mathrm{Cp}$ ve $\mathrm{Hp}$ konsantrasyonlarında bir artış görülmemiş, bu durum AFP'nin en erken 8 saat sonra yükselmesine bağlanmıştır $(7,18)$.

Farklı doğal çevresel koşula maruz bırakılan HolsteinFriesian ve Modicana ırkı sığırlarda dönemsel olarak akut faz proteinleri ölçülmüş (SAA, Hp, Fb) ve iki ırk arasında değerlendirme yapılmıştır. Yapılan değerlendirme sonucunda Modicana irkı sı̆̆ırlarda doğal olarak AFP miktarının daha yüksek olduğu, serum AFP değişimlerinin her iki ırk için de benzer değişkenlik gösterdiği, hatta bu değişimlerin sirkadiyan (dönemden döneme düzenli olarak değişen) bir tutum izlediği bildirilmiştir (20).

Olmos ve ark. (36) yaptıkları bir çalışmada Yeni Zelanda ve Kuzey Amerika kökenli Holstein 1rkı sütçü sığırların farklı besleme (Yeni Zelanda'da çayır beslemesi ve Kuzey Amerika'da entansif besleme) ve barındırma koşullarında doğuma yakın ve doğum sonrası süreçlerde kan örnekleri alarak takip etmiş ve elde ettikleri sonuçlarda genetik ataların farklı olmasından dolayı serum SAA ve Hp düzeylerinde birbirinden farklı yükselişler gördüklerini aktarmışlardır.

İki sığır ırkı (Sahiwal [İran'a ait yerel bir ırk] ve Holstein) arasında Theileria enfeksiyonunun AFP'leri üzerinde yaratmış olduğu etki araştırılmış ve kontrol döneminde Sahiwal ırkı sığırların AGP değerlerinin Holstein'lara göre daha düşük düzeyde seyrettiği bildirilmiştir (34).

Diyetlerinde değişen derecelerde tane arpa ile beslenen laktasyondaki ineklerde rumendeki endotoksin, plazma SAA ve CRP'in plazma $\mathrm{Ca}, \mathrm{Fe}, \mathrm{Zn}$, ve $\mathrm{Cu}$ ile ilişkili olduğu belirtilmiştir. Rasyona artan derecede tane yem konması AFR oluşturmada başarılı olmuş ve CRP ve SAA ölçümleri yapılmıştır. Sonuç olarak rumen endotoksinlerinde yüksek miktarda tane yem içeren rasyonlarda artış göstermiş ve plazma mineral miktarlarında hafif bir dalgalanma ve plazma SAA ve CRP konsantrasyonlarında önemli değişiklikler yapmıştır (46).

Tek sefer damar içi kortikotropin-releasing hormon (CRH) uygulaması yapılan genç Angus ırkı sığırlarda aynı zamanda serum $\mathrm{Cp}$ ve Hp miktarları saat bazında ölçülmüş, 54 saat civarında her iki AFP'ine yanıt alınmış, ancak Hp'in daha uzun süre kanda yüksek seviyelerde bulunduğu bildirilmiştir (10). Cooke ve ark. tarafından yapılmış sonraki çalışmada ise farklı iki dozda tek sefer damar içi CRH uygulaması yapılmış, düşük dozda hormon uygulanan grupta Hp miktarının ilginç bir şekilde yüksek dozda hormon uygulanan gruba göre daha yüksek olduğunu bildirmişlerdir (11).

\section{SONUÇ}

Sonuç olarak, yapılmış çalışmaların çoğunda yardımcı tanı yöntemi olarak kullanılmış olan AFP'leri bize göstermiştir $\mathrm{ki}$, bu proteinlerin ya da öncülleri olan yangısal sitokinlerin tek başlarına değerlendirilmeleri ile hayvanlardaki yangısal ya da strese bağlı oluşan hastalıklar arasında direk tanı yapılamayacaktır. Her ne kadar yapılan çalışmalar enfeksiyöz ya da non-enfeksiyöz temelinde ya da stres faktörü bazında AFP'leri irdelemiş olsa da, yanlarında tanıyı güçlendirmek için başka metabolitler de kullanmışlar ve sonuçta daha detaylı çalışmalar yapılması gerektiğini vurgulamışlardır. AFP'lerin düzeylerinin metabolizmadaki neredeyse her olumsuz durumdan etkilenmesi, bazı hassas çalışmalarda kullanılabilirliğini sınırlamıştır.

$\mathrm{Bu}$ da uzun zamandır hekimlik alanında mevcut olan proteomik kavramının daha da güçlenmesi gerektiğini bize göstermektedir. Hastalıkların ve/veya olumsuz koşulların moleküler düzeyde ve hayvanların her birinde neden farklı immun yanıt modelleri oluşturduğunun anlaşılması için bahsi geçen moleküler düzeyde araştırmalara ihtiyaç duyulmaktadır.

Yurtdışı yayınlar göstermektedir ki, AFP'leri artık yeterince çalışılmış, ancak istenen spesifik bulgulara ulaşamamış bir konu olmuştur. Yine de, var olan subklinik/klinik stres durumlarında ortaya çıkan genel tablonun takibinde metabolitler ve mineraller ile birlikte AFP'leri de iyi ve güvenilir birer yardımcı tanı elemanı olarak bilimsel çalışmalarda kullanılmaya devam edecektir.

\section{Kaynaklar}

1. Alsemgeest, S.P.M., Lambooy, I.E., Wierenga, H.K., Dieleman, S.J., Meerkerk, B., vanEderen, A.M., Niewold, T.A. (1995). Influence of physical stress on the plasma concentration of serum amyloid-A (SAA) and haptoglobin (HP) in calves. Vet Quart, 17, 9-12.

2. Ametaj, B.N., Hosseini, A., Odhiambo, J.F., Iqbal, S., Sharma, S., Deng, Q., Lam, T.H., Farooq, U., Zebeli, Q., Dunn, S.M. (2011). Application of acute phase proteins for monitoring inflammatory states in cattle. Ed(s): Veas F, Acute Phase Proteins as Early 
Non-Specific Biomarkers of Human and Veterinary Diseases, InTech Publishing, Croatia, 299-354.

3. Arthington, J. (2012). Impact of Stressors on Performance of Weaned Calves an Overview of Our Research on Acute Phase Proteins and Beef Cattle Performance. 23rd Annual Florida Ruminant Nutrition Symposium, Florida, 54-72.

4. Arthington JD, Corah LR, Blecha F (1996): The effect of molybdenum - induced copper deficiency on acutephase protein concentrations, superoxide dismutase activity, leukocyte numbers, and lymphocyte proliferation in beef heifers inoculated with bovine herpesvirus-1. J Anim Sci. 74, 211-217.

5. Arthington, J.D., Martin, F., Blecha, F. (2003). Effect of molybdenum and sulfur feeding on the acute phase protein response to inflammatory challenge in beef heifers. Prof Anim Sci. 19, 221-226.

6. Burdick, N.C., Carroll, J.A., Hulbert, L.E., Dailey, J.W., Ballou, M.A., Randel, R.D., Willard, S.T., Vann, R.C., Welsh, Jr T.H. (2010). Temperament influences endotoxin-induced changes in rectal temperature, sickness behavior, and plasma epinephrine concentrations in bulls. Innate Immun. 17(4), 355-364

7. Carroll, J.A., Arthington, J.D., Chase, C.C. (2009). Early weaning alters the acute-phase reaction to an endotoxin challenge in beef calves. J Anim Sci. 87, 4167-4172

8. Carroll, J.A., Reuter, R.R., Chase, C.C., Coleman, S.W., Riley, D.G., Spiers, D.E., Arthington, J.D., Galyean, M.L. (2009). Profile of the bovine acutephase response following an intravenous bolus-dose lipopolysaccharide challenge. Innate Immun. 15(2), 81-89.

9. Conner, J.G., Eckersall, P.D. (1988). Bovine acute phase response following turpentine injection. Res Vet Sci. 44, 82-88

10. Cooke, R.F., Bohnert, D.W. (2011). Technical note: Bovine acute-phase response after corticotrophinrelease hormone challenge. J Anim Sci. 89, 252-257.

11. Cooke, R.F., Carroll, J.A., Dailey, J., Cappellozza, B.I., Bohnert, D.W. (2012). Bovine acute-phase response after different doses of corticotropinreleasing hormone challenge. J Anim Sci. 90, 23372344.

12. Cousins, R.J. (1985). Absorption, transport, and hepatic metabolism of copper and zinc: Special reference to metallothionein and ceruloplasmin. Physiol Rev. 65, 238-309.

13. Danscher, A.M., Thoefner, M.B., Heegaard, P.M.H., Ekstrøm, C.T., Jacobsen, S. (2011). Acute phase protein response during acute ruminal acidosis in cattle. Livest Sci. 135, 62-69.

14. Dilda, F., Pisani, L.F., Rahman, M.M., Modina, S., Tessaro, I., Sartorelli, P., Ceciliani, F., Lecchi, C. (2012). Distribution of acute phase proteins in the bovine forestomachs and abomasum. Vet J. 192, 101105.

15. Dobson, H., Smith, R.F. (2000). What is stress, and how does it affect reproduction?. Anim Reprod Sci. 60-61, 743-752
16. Earley, B., Murray, M., Prendiville, D.J., Pintado, B., Borque, C., Canali, E. (2012). The effect of transport by road and sea on physiology, immunity and behaviour of beef cattle. Res Vet Sci. 92, 531-541.

17. Eaton, J.W., Brandt, P., Mahoney, J.R. (1982). Haptoglobin: A natural bacteriostat. Science. 215, 691-693.

18. Gabay, C., Kushner, I. (1999). Acute-phase proteins and other systemic responses to inflammation. $\mathrm{N}$ Engl J Med. 340, 448-454.

19. Gånheim, C., Alenius, S., Waller, K.P. (2007). Acute phase proteins as indicators of calf herd health. Vet J. $173,645-651$

20. Giannetto, C., Casella, S., Giudice, E., Marafioti, S., Fazio, F., Piccione, G. (2012). Daily rhythms of acute phase proteins in cattle under different natural environmental conditions. Livest Sci. 149, 195-200

21. Gokce, E., Atakisi, O., Kirmizigul, A.H., Unver, A., Erdogan, H.M. (2014). Passive immunity in lambs: Serum lactoferrin concentrations as a predictor of IgG concentration and its relation to health status from birth to 12 weeks of life. Small Ruminant Res. 116, 219- 228.

22. Heegaard, P.M.H., Godson, D.L., Toussaint, M.J.M., Tjørnehøj, K., Larsen, L.E., Viuff, B., Rønsholt, L. (2000). The acute phase response of haptoglobin and serum amyloid A (SAA) in cattle undergoing experimental infection with bovine respiratory syncytial virus. Vet Immunol Immunop. $77,151-159$

23. Houdijk, J.G.M., Campbell, F.M., Fortomaris, P.D., Eckersall, P.D., Kyriazakis, I. (2007). Effects of sub-clinical post-weaning colibacillosis and dietary protein on acute phase proteins in weaner pigs. Livest Sci. 108, 182-185.

24. Hughes, H.D., Carroll, J.A., Sanchez, N.C.B., Richeson, J.T. (2013). Natural variations in the stress and acute phase responses of cattle. Innate Immun, 19.

25. Kahl, S., Elsasser, T.H. (2006). Exogenous testosterone modulates tumor necrosis factor $-\alpha$ and acute phase protein responses to repeated endotoxin challenge in steers. Domest Anim Endocrin. 31, 301311.

26. Lang, U.E., Borgwardt, S. (2013). Molecular Mechanisms of Depression: Perspectives on New Treatment Strategies. Cell Physiol Biochem. 31, 761777.

27. Lecchi, C., Scarafoni, A., Bronzo, V., Martino, P.A., Cavallini, A., Sartorelli, P., Ceciliani, F. (2013). $\alpha 1-A c i d$ glycoprotein modulates phagocytosis and killing of Escherichia coli by bovine polymorphonuclear leucocytes and monocytes. Vet $\mathrm{J}$. $196,47-51$

28. Lindahl, C., Lundqvist, P., Hagevoort, G.R., Kolstrup, C.L., Douphrate, D.I., Pinzke, S., Grandin, T. (2013). Occupational Health and Safety Aspects of Animal Handling in Dairy Production. Journal of Agromedicine. 18, 274-283.

29. Lomborg, S.R., Nielsen, L.R., Heegaard, P.M.H., Jacobsen, S. (2008). Acute phase proteins in cattle 
after exposure to complex stres. Vet Res Commun. 32, 575-582.

30. Maden, M., Ozturk, A.S., Bulbul, A., Avci, G.E., Yazar, E. (2012). Acute-phase proteins, oxidative stress, and enzyme activities of blood serum and peritoneal fluid in cattle with abomasal displacement. J Vet Intern Med. 26, 1470-1475.

31. Marques, R.S., Cooke, R.F., Francisco, C.L., Bohnert, D.W. (2012). Effects of twenty-four hour transport or twenty-four hour feed and water deprivation on physiologic and performance responses of feeder cattle. J Anim Sci. 90, 5040-5046.

32. McCord, J.M., Fridovich, I. (1968). The reduction of cytochrome $\mathrm{c}$ by milk xanthine oxidase. J Biol Chem. 243, 5753-5760.

33. Murata, H. (2007): Stress and acute phase protein response: an inconspicuous but essential linkage. Vet J. 173, 473-474.

34. Nazifi, S., Razavi, S.M., Esmailnejad, Z., Gheisari, H. (2009). Study on acute phase proteins (haptoglobin, serum amyloid A, fibrinogen, and ceruloplasmin) changes and their diagnostic values in bovine tropical theileriosis. Parasitol Res. 105, 41-46.

35. Nikunen, S., Härtel, H., Orro, T., Neuvonen, E., Tanskanen, R., Kivelä, S.-L., Sankari, S., Aho, P., Pyörälä, S., Saloniemi, H., Soveri, T. (2007). Association of bovine respiratory disease with clinical status and acute phase proteins in calves. Comp Immunol Microb. 30, 143-151.

36. Olmos, G., Boyle, L., Horan, B., Berry, D.P., Sayers, R., Hanlon, A., Mee, J.F. (2009). Effect of HolsteinFriesian genetic group on peripartum and early lactation haematological and acute phase proteins profiles, health and fertility. Animal. 3(7), 10131024.

37. Orro, T., Jacobsen, S., LePage, J.P., Niewold, T., Alasuutari, S., Soveri, T. (2008). Temporal changes in serum concentrations of acute phase proteins in newborn dairy calves. Vet J. 176, 182-187.

38. Ostermann, C., Schroedl, W., Schubert, E., Sachse, K., Reinhold, P. (2013). Dose- dependent effects of Chlamydia psittaci infection on pulmonary gas exchange, innate immunity and acute-phase reaction in a bovine respiratory model. Vet J. 196, 351-359.

39. Pandey, A.K., Kar, S.K. (2011). REM sleep deprivation of rats induces acute phase response in liver. Biochem Bioph Res Co, 410, 242-246.

40. Piccione, G., Casella, S., Giannetto, C., Giudice, E., Fazio, F. (2012). Utility of acute phase proteins as biomarkers of transport stress in ewes. Small Ruminant Res. 107, 167-171.

41. Plaizier, J.C., Krause, D.O., Gozho, G.N., McBride, B.W. (2009). Subacute ruminal acidosis in dairy cows: The physiological causes, incidence and consequences. Vet J. 176, 21-31.

42. Schroedl, W., Fuerll, B., Reinhold, P., Krueger, M., Schuett, C. (2001). A novel acute phase marker in cattle: lipopolysaccharide binding protein (LBP). J Endotoxin Res. 7, 49-52.

43. Soehnlen, M.K., Aydin, A., Lengerich, E.J., Houser, B.A., Fenton, G.D., Lysczek, H.R., Burns, C.M., Byler, L.I., Hattel, A.L., Wolfgang, D.R., Jayarao, B.M. (2011). Blinded, controlled field trial of two commercially available Mycoplasma bovis bacterin vaccines in veal calves. Vaccine. 29, 5347- 5354.

44. Steele, M.A., Croom, J., Kahler, M., AlZahal, O., Hook, S.E., Plaizier, K., McBride, B.W. (2011). Bovine rumen epithelium undergoes rapid structural adaptations during grain-induced subacute ruminal acidosis. Am J Physiol Regul Integr Comp Physiol. 300, R1515-R1523.

45. Taylor, J.D., Fulton, R.W., Lehenbauer, T.W., Step, D.L., Confer, A.W. (2010). The epidemiology of bovine respiratory disease: What is the evidence for preventive measures?. CVJ. 51, 1351-1359

46. Zebeli, Q., Dunn, S.M., Ametaj, B.N. (2010). Strong associations among rumen endotoxin and acute phase proteins with plasma minerals in lactating cows fed graded amounts of concentrate. J Anim Sci. 88, 1545-1553.

47. Zebeli, Q., Mansmann, D., Sivaraman, S., Dunn, S.M., Ametaj, B.N. (2013). Oral challenge with increasing doses of LPS modulated the patterns of plasma metabolites and minerals in periparturient dairy cows. Innate Immun. 19, 298-314

Стаття надійшла до редакиії 12.10.2016 